This article was downloaded by: [Temple University Libraries]

On: 22 April 2015, At: 07:00

Publisher: Routledge

Informa Ltd Registered in England and Wales Registered Number: 1072954

Registered office: Mortimer House, 37-41 Mortimer Street, London W1T

3J H, UK

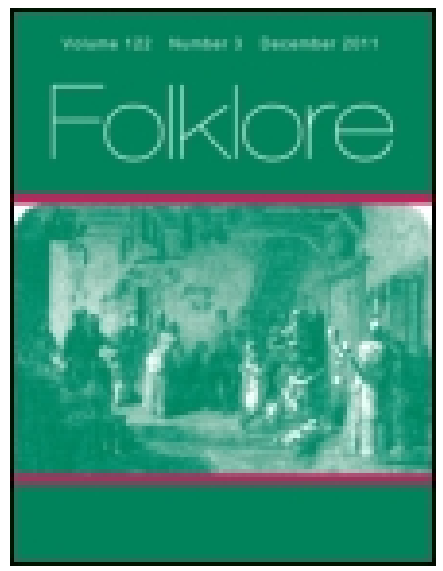

\title{
Folklore
}

Publication details, including instructions for authors and subscription information:

http:// www. tandfonline.com/loi/rfol20

\section{Secret Societies and Fetishism in Sierra Leone}

A. R. Wright

Published online: 14 Feb 2012.

To cite this article: A. R. Wright (1907) Secret Societies and Fetishism in Sierra Leone, Folklore, 18:4, 424-427, DOI: 10.1080/0015587X.1907.9719795

To link to this article: http:// dx. doi. org/ 10.1080/0015587X.1907.9719795

\section{PLEASE SCROLL DOWN FOR ARTICLE}

Taylor \& Francis makes every effort to ensure the accuracy of all the information (the "Content") contained in the publications on our platform. However, Taylor \& Francis, our agents, and our licensors make no representations or warranties whatsoever as to the accuracy, completeness, or suitability for any purpose of the Content. Any opinions and views expressed in this publication are the opinions and views of the authors, and are not the views of or endorsed by Taylor \& Francis. The accuracy of the Content should not be relied upon and should be independently verified with primary sources of information. Taylor and Francis shall not be liable for any losses, actions, claims, proceedings, demands, costs, expenses, damages, and other liabilities whatsoever or howsoever caused arising directly or indirectly in connection with, in relation to or arising out of the use of the Content.

This article may be used for research, teaching, and private study purposes. Any substantial or systematic reproduction, redistribution, reselling, loan, sub-licensing, systematic supply, or distribution in any form to anyone is 
expressly forbidden. Terms $\&$ Conditions of access and use can be found at http://www.tandfonline.com/page/terms-and-conditions 


\section{COLLECTANEA.}

\section{Secret Societies and Fetishism in Sierra Leone.}

THE objects shown in Plates VIII., IX., and X., most of which were exhibited at the Society's meeting on June rgth, illustrate the appliances of some of the highly-developed secret societies and the fetish beliefs of the tribes in the Sierra Leone Protectorate. They were obtained from traders and officials who have travelled in the interior.

The most important society is the Porro, a detailed account of which is given in $A$ Revelation of the Secret Orders of Western Africa (Dayton, Ohio, 1886, 99 pp.), by Rev. J. A. Cole of Shaingay, who was of pure negro blood and had been initiated. A description is also given by Mr. T. J. Alldridge in The Sherbro and its Hinterland. The society in its usual form appears to be a kind of freemason and benefit club for men only, and Mr. Cole describes signs, passwords, and seven grades which he compares to grades in European freemasonry. He explains Porro or Purroh to mean "the ancient and sacred laws of the fathers." The society trains, circumcises, tattoos, and re-names the boys of the tribes, and is substantially the native government of the country. The oaths of secrecy taken are enforced by fetish sanctions and ceremonies, and the society can put a rigid taboo on any person or thing. The mask shown in Fig. I was worn by a personator of the krifi $k a$ porro, or porro "devil," a spirit who may not be seen by women or non-members, and who is supposed to devour candidates for the society, and afterwards give them birth again, returning to the sky. The mask is carved from a solid block, and is 
about $16 \frac{1}{2}$ inches high, with an internal diameter of 81 inches. It is perforated with a number of holes to allow the wearer to breathe, and the dressing of the hair is carved in high relief. Holes near the lower rim of the mask serve for the attachment of a long robe of shaggy, black-dyed palm fibre. One of the principal officers of the Porro society is the tasso or ba-kasey (lawyer), who wears attached to his knees rattles of one of the forms shown in Figs. II and 12. The rattle in Fig. II is a bent plate of native iron containing a loose iron lump, while in Fig. 12 it is a longer and narrower bent plate (which may originally have contained a loose lump), with two loose jingling rings suspended at each end (Plate X.).

The Bundu or Bondo society is the initiation society for girls, and the normeh, or Bundu "devil," who avenges all interference with Bundu laws and taboos, and leads the girls at galas, etc., wears the mask shown in Fig. 2 (Pl. VIII.). This mask is not perforated, and it is therefore necessary from time to time for the normeh to take it off, which is done under the shelter of a large mat unrolled round the "devil" by an attendant. The mask has been carved from a solid block of cotton-wood and blackened, and the carved hair-dressing is of a pattern greatly favoured by the native women. The dress worn with this mask is of rough black palm fibre, sewn up at the ends of the arms and legs so that no part of the body can be seen, and the dress in my possession has a number of jingling seeds attached to the waist. This "devil," although the women's devil and personated by a woman, never speaks, but conveys her orders by signs. The Bundu girls, during their training in dancing, deportment, medicine, and so on, by the mesu or "mother of the maids," are painted all over with wojeh, a mixture of white clay and animal fat which is credited with magical and protective properties, and the wojeh is used from the palette shown in Fig. 3. The palette ends in a head, on the neck of which are two horns having a fetish meaning. Similar horns appear on the neck of a minsereh figure (see below) in my possession which is not illustrated. Wojeh is also used to trace devices by the finger on the foreheads of the country belles. 
Piate liII.

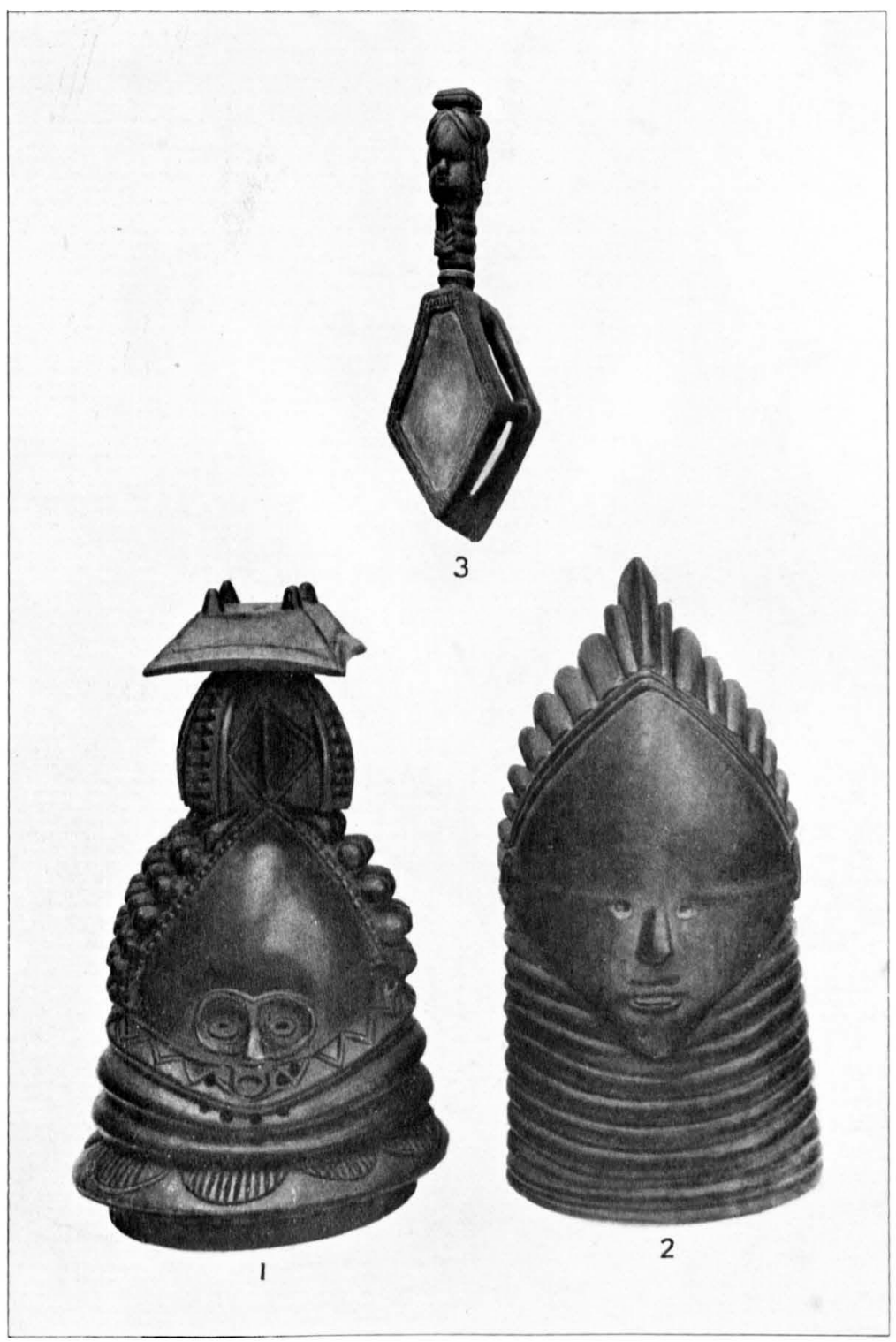

MASKS, ETC., OF PORRO AND BUNDU SOCIETIES.

To jaci to. +2.1 . 
Plate IX.

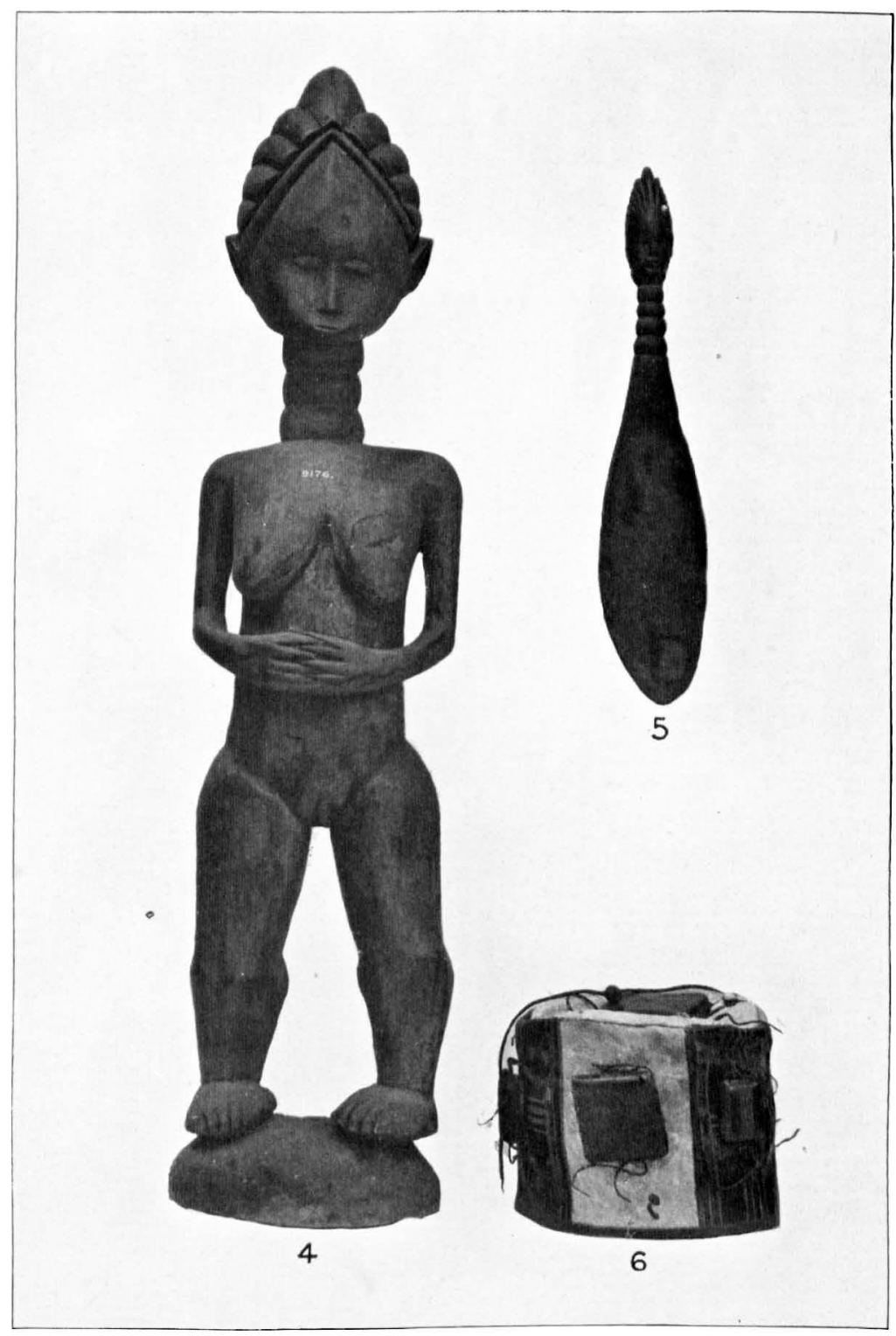

YASSI SOCIETY MINSEREH FIGURE, ETC.

7o face ค. 425 . 
A third society, the Yassi or Yasey, consists of women who already belong to the Bundu and of Porro men. The Yassi official Ya-mama can enter the Porro lodge by a private passage. Everything belonging to the Yassi must be spotted with coloured patches, except the black minsereh figures, Fig. 4, which are kept in the Yassi house near the fetish medicine. To obtain information from the fetish, the Ya-mama anoints the figure with the medicine, brings it out from the Yassi house with certain ceremonial, and holds it out by both hands at the waist, so that it can swing, the figure being made of light wood. Should the answer to the question put be favourable, the figure gradually inclines towards the Ya-mama. The figure shown is 32 inches high. (Plate IX.)

The Human Leopard Society is one charged by most accounts with cannibalism, either ceremonial or with a fetish excuse for obtaining human flesh in time of peace. The main object of the society appears, however, to have been to obtain human fat to anoint, and so bring into activity, a made-up fetish such as Bai Bureh's bofimah or "medicine-bag,"-shown in Fig. 7 . Bai Bureh was the principal leader of the Timini against the British in the rising of $1898-9$, and used this fetish for thoughtreading and forecasting events. It consists of a hardened paste surrounded by several layers of cloth covered outside by red cloth, stiffened by pieces of cane, and bound in sausage form by cord. A small horn was originally attached, but has unfortunately been lost. The Human Leopard Society began about 40 years ago, and each member was required, on entry and, some say, also every fourth year, to supply a victim. The society's slayer lurked in the bush until the designated prey passed, and then leaped on him from behind with a leopard's cry, and drove into the back of his neck the forked knife shown in Fig 9. The body was then cut open to obtain the fat which enabled the bofimah to grant any wish. Sometimes the leopard's claws were imitated, not by the forked knife shown, but by a leopard-skin glove fitted with curved sharp blades. A new member was recruited by inviting him to a feast, giving him a little human flesh 'unbeknownst,' and then telling him what he had eaten, and that he would die 
unless he became a member. The natives appear to have themselves tried to exterminate the society. According to evidence given at the enquiry before Sir D. P. Chalmers into the insurrection in Sierra Leone in 1898, it appears that about I880-I the chief of Tyama detected nearly roo members, and burnt them. In I883-4 a chief of Mano, called Cardini, burnt a sub-chief and about 80 others as members, and there are other instances. Nevertheless the society survived, and it was found necessary in 1896 to pass "The Human Leopard and Alligator Society Ordinance" for its suppression. It is the native story that the bofimah was originally kept alive by goats, but that a tribe whose ambush had been betrayed by the Imperri people in revenge sent the fetish into the Imperri country and decreed that human sacrifices were in future necessary.

A fetish spoon is shown in Fig. 5 (Pl. IX.), and an example of a fetish which is practically only an amulet in Fig. 8 (Pl. X.), which represents a charm called banyehn, II $\frac{1}{2}$ inches long, and made of country iron in the form of tongs or pincers with spirally-twisted handles. Tongs or pincers are not uncommon as amulets. A pair occurs, for example, amongst a number of objects depending from an amuletic necklace in my possession which came from Nish in Servia.

The wandering Mohammedan "Mori men" or "book men" are looked on in the Protectorate as magicians, and have a monopoly of the supply of written charms. These are made up as sebbehs in leather cases, and Fig. 6 (Pl. IX.) shows some specimens attached to Bai Bureh's war cap. This cap is made of skin prepared in alternate strips of white and brown. Six sebbehs of various sizes are attached to the sides of the cap, and one large one with eight cowries to the top.

Fig. 1o shows a specimen of the steatite nomori or "farm devil" figures, which differs somewhat from the figures described and illustrated in Man for 1905 (pp. 97-roo). Such figures are found by digging in the fields or in mounds far inland, and, as the present natives do not know how to carve steatite, the figures are probably the work of an extinct tribe. They are greatly valued, and are set up in the fields and whipped in 
Plate $X$.

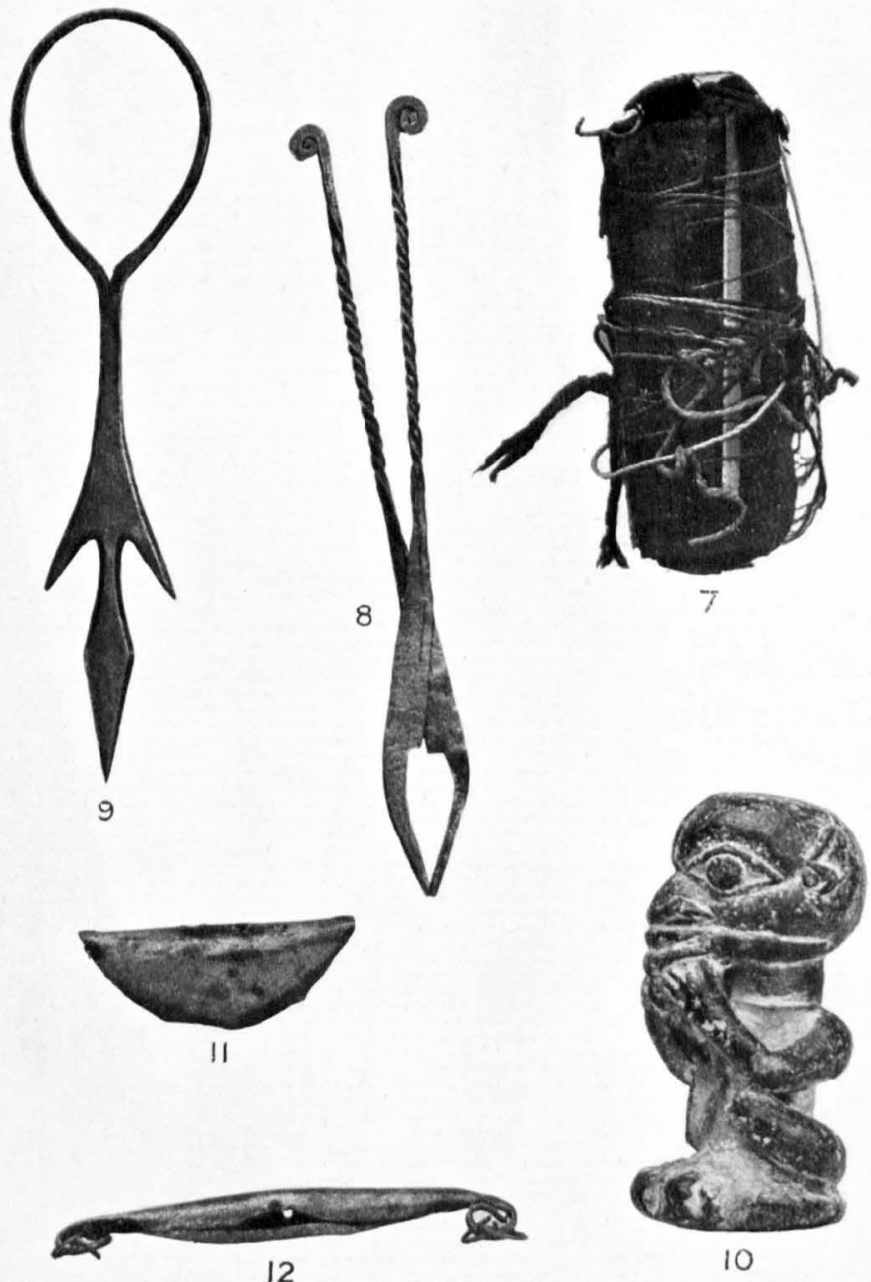

BOFIMAH, NOMORI, AND OTHER FETISH OBJECTS. 
order to induce them to steal rice from the fields of others to plant in their owner's land. Sacrifices are offered to them, and their powers are greatly increased if they have been stolen. (Cf. vol. vi., p. 196.) The figure is 61 inches high, and has the usual vertical hole in the top of the head. It is seated, and perfect, except that the portion of the legs between the knees and feet is missing.

A. R. WRIGHT.

\section{Folk Traditions of the MUghal Emperors. ${ }^{1}$}

THE following tales relating to the Mughal period in India were collected by Muhammad Husain Khãn of the Muhammadan Anglo-Oriental College, Aligarh, in the United Provinces of Agra and Oudh, India, from peasants in the Panjāb. They are very popular among the higher classes. I am not aware whether variants of them are current among the people of other parts of Northern India; but, as far as it has been possible to ascertain, they are found in much the same form throughout the whole of the Panjab.

The Mughal period may be said to commence with the overthrow, in 1526 A.D., of the reigning king, Ibrahim Lodi, by Bābar, a descendant of Genghis Khān and Timūrlang or Tamerlane. On his death in $153^{\circ}$ he was succeeded by his son Humãyan, who was driven for a time from his throne by an adventurer of Afghān descent, Shīr Shāh. On his death in $155^{6}$ the crown passed to his son Akbar, whose long reign of 49 years covers the greatest period of the Mughal Empire. His son Jahāngir was followed in 1628 by Shāh Jahān, to whom we are indebted for some of the finest architectural monuments of his dynasty-the new city of Delhi, the Tãj Mahal at Agra. The reign of his son Aurangzib ( $165^{8-1}$ 707) marks the decadence of the Empire, largely due to the growth of the new Mahratta power in the Deccan.

Karim Haidar Lodi.

${ }^{1}$ With Notes by W. Crooke. 